\title{
De opmars van de empathische computer
}

In, op en om ons lichaam gaat het allemaal gebeuren. De huidige brillen, horloges en armbanden zijn pas het begin. Het wordt al empathic computing genoemd, alle wearables die de relatie mens-machine heel intiem gaan maken. Dagelijkse waarneming laat al zien dat het apparaat voor veel mensen vaak interessanter is dan het gezelschap. Nu wordt deze relatie met de machine ook nog erg intiem. Informatie over onze stemming, onze mate van vermoeidheid, angst, agressie en natuurlijk de hersengolven; alle biologisch een fysiologische grootheden worden straks gemeten, opgeslagen en gecommuniceerd met interventies als gevolg. Een actueel voorbeeld: een touringcarbedrijf werkt met een nieuw systeem dat de vermoeidheid detecteert bij buschauffeurs. Deze 'Seeing machines' monitoren het gedrag in de cabine. Gelaatsuitdrukkingen worden gevolgd, bij dreigende vermoeidheid krijgt de chauffeur via de stoel een schokje toegediend en een slapende bijrijder wordt automatisch gewekt. Informatie over afwijkend gedrag wordt naar de server op het hoofdkantoor gestuurd. De gehele installatie kost vijfduizend euro per bus. In ons lichaam worden straks devices aangebracht die ons angstniveau, onze irritatie en onze algehele stemming op basis van fysiologisch gegevens sneller detecteren dan we dat zelf kunnen, waarna er op basis van psycho-neuro-immunologisch onderzoek meteen interventies worden toegepast die de toestand normaliseren; interventies die zijn aangepast op de persoon in kwestie (intiem).Een digitaal identiteitsbewijs kan nu al in de vorm van een pil worden ingeslikt, waardoor bepaalde bevoegdheden met je meelopen. Kunstmatige intelligentie stuurt in toenemende mate ons leven en onze gezondheid.

Wat betekent dit voor de ggz? Psychische aandoeningen nemen niet toe ${ }^{1}$, maar ook niet af. Er wordt wel veel meer hulp gevraagd en steeds meer gediagnosticeerd en behandeld, maar de behandelingen hebben een beperkt structureel effect; patiënten met een ernstige paniekstoornis, fobie, depressie, of andere ernstige psychiatrische aandoening moeten hun hele leven rekening mee houden dat deze kwetsbaarheden nooit meer helemaal overgaan en dat de kans op terugval reëel is. Dragen we met alle behandelingen geen water naar de zee? Een weliswaar ongepaste maar verhelderende vergelijking: infectieziektes sterven ook niet uit, die vormen nog steeds een probleem, maar preventieve vaccinatie en preventieve hygiëne zijn wel erg behulpzaam bij het voorkomen van veel belastende vormen ervan. Onze moeizame en tijdrovende psychologische en psychiatrische behandelingen gaan het afleggen tegen de microtechnologie die ons in, op en om het lichaam gaat bijsturen. Dit is de evolutie, die houden we niet tegen. De psychotherapie verdwijnt aangezien deze niet goed is aangepast aan onze technologische revolutie. In plaats van de empathische psychotherapeut komt de empathische machine, met veel meer mogelijkheden die uiteindelijk ook veel goedkoper en efficiënter zijn.
Maar de kennis die in de nu nog bestaande behandelpraktijk aanwezig is, mag niet verloren gaan. De inzichten en klinische ervaringen die in klinische psychologie en psychiatrie beschikbaar zijn, kunnen zinvol worden ingezet om vooral vroegkinderlijk condities te verbeteren. De preventie van psychische en psychosomatische aandoeningen via alleen al het verspreiden van kennis en het aanleren van vaardigheden bij jonge ouders over gehechtheidspatronen en processen gedurende de eerste 1000 dagen (geteld vanaf de conceptie) kan zeer succesvol worden. In die 1000 dagen verdubbelen de hersenen in gewicht en worden deze op een uniek wijze gevormd in de affectieve moeder(vader)-kind relatie. Hiervan weten we op basis van goed onderzoek al veel.

Mijn oproep aan alle werkers in de ggz: bepleit binnen je organisatie dat je de helft van de tijd aan preventie kunt besteden. Het goud dat je hebt gedolven in de behandelpraktijk kun je nu implementeren in de preventiepraxis voor het te laat is. Hiermee help je nog veel meer mensen dan tot nu toe via behandeling. Overheid, beleidsmakers en zorgverzekeraars kunnen op termijn veel besparen indien ze deze tijd nu gaan financieren. Overtuig ze daarvan en doe dat via een wake-up call: alle ggz-werkers staken komend najaar een dag en trekken dan demonstratief naar de kantoren van de zorgverzekeraars verspreid over het land en naar Den Haag. Empathic computing doet straks de rest.

De in totaal 55 verschenen nummers van GZ-Psychologie, met meer dan 500 artikelen, hadden de inzet onze beroepsgroep te versterken. Sinds ik psychologie studeer (1973) kan ik me niet aan de indruk onttrekken dat onze beroepsgroep altijd beter was in opsplitsen dan in fuseren. Ongetwijfeld had dit te maken met onze identiteit; overal ter wereld, in allerlei sectoren wordt opgesplitst om een identiteit te zoeken of om die te versterken. De naderende fusie van de twee psychologenbladen GZ-Psychologie en PsychoPraktijk dient een krachtige beroepsgroep. Een psycholoog met een gezond zelfvertrouwen is een effectievere diagnosticus en behandelaar voor de mensen die hulp zoeken. Wat mij betreft is het opsplitsen, ook binnen de diverse organisaties die ons beroep kent, voorbij en kunnen we ook verder organisatorisch samengaan zonder vertrouwen te hoeven verliezen in de bijdrage van psychologen aan het psychische welzijn. Ik heb mijn columns en andere bijdragen aan dit tijdschrift met plezier geschreven.

Prof. Dr. Jan Derksen is klinisch psycholoog en was hoofdredacteur van GZ-psychologie..

${ }^{1}$ Iedereen een psychische aandoening? Utrecht; De Tijdstroom, 2015. 